\title{
DE ANQUIN SYNDROME-RARE CAUSE OF LOW BACK PAIN: A CASE REPORT WITH REVIEW OF LITERATURE
}

\author{
Spasov Marko, Todorov Ilija, Stojkovska-Pemovska Emilija \\ University clinic of Traumatology, Medical faculty of Skopje, Macedonia
}

Primljen/Received 09. 05. 2016. god.

Abstract: Introduction: Low back pain is common medical disorder that can be caused by different etiologies, some of them being very rare. During the past decades, much of the etiology and pato-mechanics of low back pain has been clarified. However, defining precise cause of low back pain in a small subset of patients is still challenging.

Case presentation: We are presenting a case of long lasting low back pain caused by impingement of the enlarged spinous process of the fifth lumbar spine into the spina bifida of the first sacral segment, so called De Anquin syndrome. We delineated the precise morphology of the anomaly using CT scans, and since the patient was symptomatic, the resection of the enlarged spinous process was undertaken. During the follow up period, the patient remained completely symptom free.

Discussion and Literature review: We undertook literature review and small number of studies describing De Anquin syndrome were found. The most remarkable finding of the case presented is the immediate and complete release of pain.

Conclusion: We do recommend seeking for the exact etiology in the patients with long lasting low back pain.

Keywords: De Anquin syndrome, low back pain, clasp knife deformity, sciatica.

\section{INTRODUCTION}

Low back pain is common medical complaint. The condition itself is associated with significant disabilityand considerable cost (1). It isestimated that up to $84.1 \%$ of the general populationhave experienced low back pain during their lifetime (2). It is the most common reason for visits to the orthopedic surgeons and neurosurgeons (3). The annual prevalence of chronic low back painranges from $15 \%$ to $45 \%$, with a point
Prihvaćen/Accepted 12.06. 2016. god.

prevalenceof $30 \%(2,4-7)$. Contrary to the common belief that low back painprevalence remains the same, (8) studies have shown alarming increase in the past two decades (9-13). The percentage of the workforce affected varies from $2 \%$ to $8 \%$ with days of absence ranging from 9 days inthe United States, to 40 days inSweden, per pt. per year $(13,14)$.

Low back pain is a disorder with manypossible etiologies, occurring in different groups of the population.Despite high prevalence and research, there is still professional uncertainty about optimal therapeutic approach (15). During the past decade, huge scientific work and widespread use of imaging studies have clarified much of the etiology and pato-mechanics of low back pain (6). Seeking for the exact etiology is mandatory in patients with long lasting low back pain and failure of conservative therapy (9). In such instances, high level of suspicion for rare etiology as a possible cause for low back pain should be present.

We are reporting a patient who suffered long lasting low back pain caused by very rare congenital osseous anomaly of the lumbosacral junction known as clasp-knife deformity or de Anquin syndrome.

\section{CASE PRESENTATION}

A 43-year-old man presented to the outpatient clinic for evaluation of the low back pain. The current episode of low-back pain started 2 months ago. At the beginning, the pain was localized at his lower back, but subsequently it became radiating along his both legs. He also noticed that his sexual function started to deteriorate and bowel habits become irregular.

His past medical history is remarkable. He had suffered cerebral palsy in his childhood, having gait impairment as a consequence. He also hasprognathiathat was surgically treated and lumbar spondylolisthesis for which he underwent surgical treatment eight years 
ago. After the last surgery, he remained symptom free for two years when he started to experience some pain in the central part of his lower back. This time, the pain developed during his regular air-pistol shooting practice. Subsequently, the patient noticed that the pain is occurring at the time when the back is hyperextended, while performing his daily routines and during sleeping on his back. Furthermore, he realized that the pain is relieving by flexion of the back. Since then, the episodes become more regular and disabling, requiring increasing doses of analgesics and frequent courses of physical therapy. The symptom free periods become shorter, lasting no more than month or two.

During the days before the actual examination, the pain while standing and walking caused considerable suffering and forced the patient to come to the clinic on a wheelchair. The patient was well developed individual and his back was straight. Vital signs, regular lab findings were within the normal range.Both flexion and extension of low back were quite limited and very painful. The clinical exam revealed healed surgical

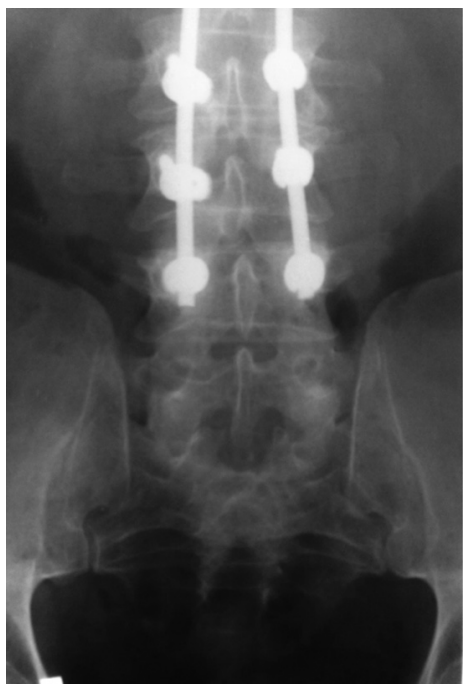

Figure 1. Preoperative radiography demonstrating spina bifida occulta on the first sacral segment scar in the midline of his back from a previous operative fixation of the spondylolisthesis at the level of the second and third lumbar vertebrae. Palpation at that level did not reveal any pain. As the palpation of the spinous processes was going downwards, he reported intense pain at the level over the lumbo-sacral junction and upper part of the sacrum. We did not note any atrophy of the gluteal, thigh and calf muscles. Spasm of the lumbar musculature was present on both sides.

Neurological examination demonstrated signs of nerve root compression. Namely, the pain was radiating along his both legs and deep tendon reflexes were diminished. The rectal tone was also decreased. Motor power was difficult to test accurately because of the intense pain caused by manipulation and positional changes. The findings of the sensory examination were also remarkable. Pain and numbness were present in multiple dermatomas, most affected being L5 and S1 dermatome. Pain on straight leg rising was not present.

The point of maximum tenderness was marked with a ruler and radiographies of the lumbo-sacral spine were ordered. Roentgenograms of the lumbosacral spine (Figure 1) showed slight reduction in the normal lumbar lordosis, possibly associated with the muscle spasm.

The point of maximum tenderness precisely corresponded with the lumbosacral junction. Focused anteroposterior view of the lumbosacral junction revealed spina bifida at the level of fifth lumbar vertebra which was overlooked in the previous radiology exams. On a profile view, the spinous process looked enlarged and elongated. In order to delineate the precise morphology of the lumbosacral junction, CT scan was ordered (Figure 2).

The findings revealed excessively large, elongated and hooked spinous process of the fifth lumbar vertebra intruding into the osseous defect over the first sacral segment. Additionally, electromyography findings demonstrated reduced sensomotor conductivity originating from the fourth and fifth lumbar nerve roots as well as first two sacral roots.
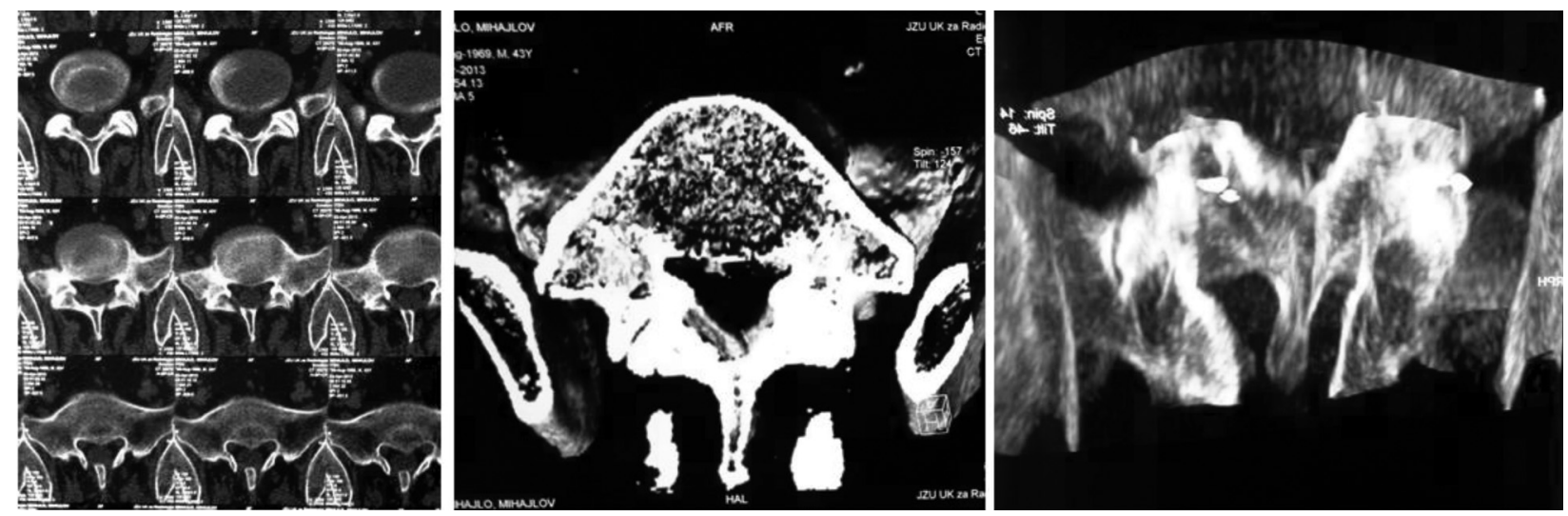

Figure 2. Transverse CT scans demonstrating laminar defect and adjacent spinous process protruding into the defect (left) and 3-D reconstructions at the same level (middle and right) 

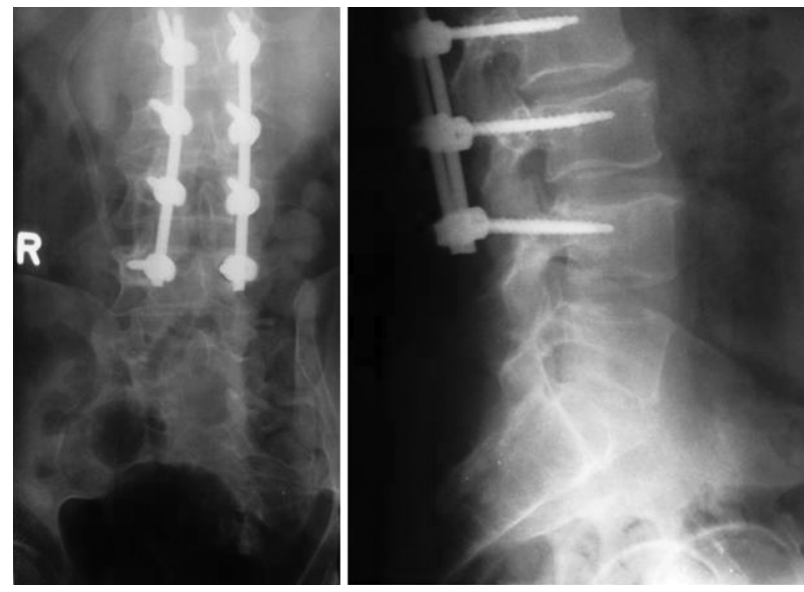

Figure 3. Postoperative radiographies

It was clear that the pain and neurologic deficit could be attributed to the impingement of the fifth spinous process on a sacral spina bifida.

Since the conservative treatment was unsuccessful, the pain was increasing and the neurologic deficit occurred, we decided to operate on the patient.

The lumbosacral junction was exposed through the midline incision. We exposed the spina bifida and defined its limits. The fifth lumbar spinous process was excised by cutting it off at its base and by separating adhesions between it and the fibrous membrane across the posterior osseous defect of the first sacral segment. Postoperative radiographies are shown on Figure 3.

Postoperative period went uneventful. Operative wound healed with no complications. During the immediate postoperative check up the patient reported that the pain while lying on his back as well as the pain along his both legs has diminished. In the next few days of his hospital stay we undertook regular neurologic examinations. The complete neurologic recovery was evident, including tendon reflexes and sphincter function.
Outpatient clinic checkups were undertaken at four weeks, three months and six months and a year post surgery. During the follow up period the patient was completely symptom free and satisfied with the surgery. Neurologic examinations revealed complete recovery.

\section{DISCUSSION}

\section{AND LITERATURE REVIEW}

Low back pain is a common medical complaint with prevalence as high as $73 \%$ (2). In most cases, it subsides with no medical treatment or short courses of physical therapy. However, in less than $1 \%$ of cases low back pain is caused by congenital deformity of the spine (8). Since its first description in 1875 by Virchow, spina bifida occulta alone has usually been addressed as a cause of low back pain $(16,17)$. The association between spina bifida occulta and enlarged spinous process of the fifth lumbar spine was first described by Ferguson in 1934 (18). He indicated the possibility of existence of a free remnant of the first sacral spinous process or a single enlarged and hooked spinous process of the fifth lumbar spine that intrudes into the posterior defect of the first sacral segment thus compressing the dural sac and producing pain.

To our knowledge, there are only few papers focusing on spinous engagement syndrome. The literature search was conducted in order to identify papers focusing on de Anquin syndrome. "Pubmed Medline" and "Google Scholar", without language and publication date limitation, were searched. The following search terms and Boolean operators were used: de Anquin syndrome or de Anquin disease or Morbus de Anquinor Spinous impingement syndrome or Spinous engagement syndrome. In order to complete the list of published studies, we also searched the reference lists of already detected studies. The search results are presented in Table 1.

Table 1. Overview of the studies

\begin{tabular}{|c|c|c|c|c|c|}
\hline Study & Year & Patients & Treatment & Outcome & Comment \\
\hline $\begin{array}{l}\text { Ferguson } \\
\mathrm{AB}\end{array}$ & 1934 & single case & $\begin{array}{l}\text { no treatment } \\
\text { described }\end{array}$ & $\begin{array}{l}\text { no outcome } \\
\text { described }\end{array}$ & $\begin{array}{l}\text { radilogic study presenting } x \text {-rays } \\
\text { of a single case with this anomaly }\end{array}$ \\
\hline $\begin{array}{l}\text { Bellerose } \\
\text { MN }\end{array}$ & 1935 & single case & $\begin{array}{l}\text { no treatment } \\
\text { described }\end{array}$ & $\begin{array}{l}\text { no outcome } \\
\text { described }\end{array}$ & morphological study \\
\hline $\begin{array}{l}\text { De Anquin } \\
\text { CE }\end{array}$ & 1959 & 15 cases & $\begin{array}{l}\text { conservative in } 4 \text {, } \\
\text { operative in } 11 \\
\text { patients }\end{array}$ & $\begin{array}{l}\text { excellent results in } \\
\text { operatively treated } \\
\text { patients }\end{array}$ & $\begin{array}{l}\text { the first study to describe the anomaly and } \\
\text { treatment options in detail }\end{array}$ \\
\hline $\begin{array}{l}\text { Stark } \\
\text { WA }\end{array}$ & 1971 & single case & operative & described as good & $\begin{array}{l}\text { the anomaly was diagnosed } \\
\text { intraoperatively }\end{array}$ \\
\hline $\begin{array}{l}\text { Goobar JE } \\
\text { et al }\end{array}$ & 1988 & 2 cases & conservative & $\begin{array}{l}\text { some success with } \\
\text { conservative } \\
\text { treatment }\end{array}$ & $\begin{array}{l}\text { the authors do not discuss the possibility } \\
\text { of operative treatment }\end{array}$ \\
\hline Bruns J et al & 1994 & 6 cases & $\begin{array}{l}\text { operative in all } \\
\text { patients }\end{array}$ & $\begin{array}{l}\text { immediate release } \\
\text { from or decrease in } \\
\text { pain in all patients }\end{array}$ & most detailed description of the syndrome \\
\hline $\begin{array}{l}\text { Dieckmann C } \\
\text { et al }\end{array}$ & 1995 & 6 cases & $\begin{array}{l}\text { operative in all } \\
\text { patients }\end{array}$ & $\begin{array}{l}\text { excellent in } 3 \\
\text { patients }\end{array}$ & $\begin{array}{l}\text { revision of the nerve roots and division } \\
\text { of adhesions performed }\end{array}$ \\
\hline
\end{tabular}


Bellerose reported one case of a patient with enlarged and curved spinous process of the fifth lumbar vertebra protruding into the adjacent spina bifida occulta (19). De Anquin was the first to describe this peculiar anomaly in detail (17). He published a study of 15 patients suffering low back pain caused by spinous engagement at the lumbosacral junction. Eleven out of 15 patients in his study were treated operatively, with excision of the fifth lumbar spinous process and a good clinical outcome. He also described two different types of the syndrome. Type I is characterized with pain at the lumbosacral junction caused by protrusion of the enlarged fifth lumbar spine into the posterior defect of the first sacral segment with no signs of nerve root compression, while type II is associated with nerve root compression. In 1971, Stark reported on a case of de Anquin syndrome with signs of nerve root compression (20). The patient was operated with excision of the fifth lumbar spinous process and posterior lumbosacral fusion. Goobar et aldescribed two cases of de Anquin syndrome that were treated conservatively that led to decrease in the severity of the symptoms (21). They used the term "dynamic type of stenosis" to explain the pain producing mechanism in these two patients. In 1994, Bruns et al published a study of 6 patients with long lasting low back pain caused by de Anquin syndrome (22). All of them were treated operatively after numerous courses of physiotherapy. According to their results, the most impressive finding was the immediate decrease in pain reported by all patients included in the study. However, remaining complaints of two of the patients were attributed to the osteoarthritic changes of lumbosacral facets.In 1995, Diec- kmann published study of six operatively treated patients, with result very similar to those of Bruns (23).

We are reporting on a case of a young individual who practices active lifestyle despite serious comorbidities. Our decision to operate on the patient was based on the findings of abovementioned studies and case reports, ineffective attempts of conservative treatment for few years and the progressivenessof the neurologicdeficit. The most remarkable finding was immediate and complete postoperative release of pain. Subsequently, he also regained bowel and urinary sphincter function, as well as sexual function. Our postoperative result is similar to those described in the literature.

\section{CONCLUSION}

Despite being very common, low back pain can be caused by rare and curable etiologies. Presence of low back pain associated with spina bifida occulta should always raise the suspicion of coexistence of spinous impingement caused by enlarged adjacent spinous process. Awareness of the existence of this peculiar anomaly is the cornerstone in the treatment of these patients. The treatment itself is straightforward and consists of simple surgical excision of enlarged spinous process. Published studies and case reports have shown excellent clinical outcomes following surgical treatment.

\section{Conflict of interest}

The authors have no conflict of interests to declare.

\title{
Sažetak
}

\section{DE ANQUIN SINDROM — REDAK UZROK BOLAU DONJEM DELU LEĐA: PRIKAZ SLUČAJA I PREGLED LITERATURE}

\author{
Spasov Marko, Todorov Ilija, Stojkovska-Pemovska Emilija \\ University clinic of Traumatology, Medical faculty of Skopje, R. Macedonia
}

Uvod: Bol u donjem delu leđa je čest zdravstveni problem koji može biti uzrokovan različitim etiološkim faktorima, a neki od njih su vrlo retki. Tokom proteklih decenija, većina etioloških faktora i patoloških mehanizama bola u donjem delu kičme je razjašnjena. Međutim, definisanje tačnog uzroka ovog bola kod malog broja pacijenata i dalje je izazov.

Prikaz slučaja: Predstavljamo slučaj dugotrajnog bola u donjem delu kičme, uzrokovanog udaranjem uvećanog spinoznog nastavka petog lumbalnog pršljena u spinu bifidu prvog sakralnog segmenta, što karakteriše takozvani De Anquin-ov sindrom. Identifikovali smo tačnu morfologiju anomalije pomoću CT-a, a budući da je pacijent imao simptome, izvršena je resekcija uvećanog spinoznog nastavka. Tokom perioda praćenja, pacijent je bio potpuno bez tegoba.

Diskusija i pregled literature: Pregledom literature pronađen je mali broj studija koje opisuju De Anquin sindrom. Najznačajniji nalaz kod prezentovanog slučaja je to što je došlo do neposrednog i potpunog oslobađanja od bola.

Zaključak: Preporučujemo precizno ispitivanje etiologije kod pacijenata sa dugotrajnim bolovima u donjem delu leđa.

Ključne reči: De Anquin syndrome, bol u donjem delu leđa, clasp knife fenomen, išijas. 


\section{REFERENCES}

1. Chou R, Shekelle P. Will this patient develop persistent disabling low back pain? Jama. 2010; 303(13): 1295-302.

2. Cassidy JD, Carol Lj, Côte P. The Saskatchewan Health and Back Survey. The prevalence of low back pain and related disability in Saskatchewan adults. Spine. 1998; 23(17): 1860-7.

3. Cypress BK. Characteristics of physician visits for back symptoms: a national perspective. Am J Public Health. 1983; 73(4): 389-95.

4. Leboeuf-Yde C, Lauritsen JM. The prevalence of low back pain in the literature. A structured review of 26 Nordic studies from 1954 to 1993. Spine (Phila Pa 1976). 1995; 20(19): 2112-8.

5. Manckhikanti L. Epidemiology of low back pain. Pain Physician. 2000; 3(2): 167-92.

6. Deyo RA, Mirza SK, Martin BI. Back pain prevalence and visit rates:estimates from U.S. national surveys, 2002. Spine (Phila Pa 1976). 2006; 31(23): 2724-7.

7. Loney LP, Stratford PW. The Prevalence of low back pain in adults: a methodological review of the literature. Phys Ther. 1999; 79(4): 384-96.

8. Deyo RA, Weinstein JN. Low back pain. N Engl J Med. 2001; 344(5): 363-70.

9. Freburger JK, Holmes MG, Agans RP, et al. The rising prevalence of chronic low back pain. Arch Int Med. 2009; 169(3): 251-8.

10. Stewart WF, Ricci JA, Chee E, Morganstein D, Lipton R. Lost productive time and cost due to common pain conditions in the US workforce. JAMA. 2003; 290(18): 2443-54.

11. Ricci JA, Stewart WF, Chee E, Leotta C, Foley K, Hochberg MC. Back pain exacerbations and lost productive time costs in United States workers. Spine (Phila Pa 1976). 2006; 31(26): 3052-60.

12. Nachemson AL. Newest knowledge of low back pain. A critical look. Clin Orthop Relat Res. 1992; 279:8-20.

13. Nachemson A.L. Advances in low-back pain. Clin Orthop Relat Res. 1985; 200: 266-78.

14. Marras WS, Ferguson SA, Burr D, Schabo P, Maronitis A. Low back pain recurrence in occupational environments. Spine (Phila Pa 1976). 2007; 32(21): 2387-97.

15. Atlas SJ, Deyo RA. Evaluating and managing acute low back pain in the primary care setting. J Gen Intern Med. 2001; 16(2): 120-31.

16. Jelsma F, Ploetner EJ. Painful spina bifida occulta; with review of the literature. J Neurosurg. 1953; 10(1): 19-27.

17. De Anquin C. Spina bifida occulta with engagement of the fifth lumbar spinous process. J Bone Joint Surg Am. 1959; 41B(3): 486-90.

18. Ferguson AB. The clinical and roentgenographic interpretation of lumbosacral anomalies. Radiology. 1934; 22(5): 548-58.

19. Bellerose MN. Low back pain caused by lumboacral abnormalities. N Engl J Med. 1935; 213(4): 177-81.

20. Stark WA. Spina bifida occulta and engagement of the fifth lumbar spinous process. Clin Orthop Relat Res. 1971; 81(1): 71-2.

21. Goobar DJ, Erickson F, Pate D, Sartoris DJ, Resnick D. Symptomatic clasp-knife deformity of the spinous processes. Spine (Phila Pa 1976). 1998; 13(8): 953-6.

22. Bruns J, Rehder U, Dahmen GP, Behrens P, Meiss L. Morbus de Anquin or spinous engagement syndrome. A rare cause of low-back pain syndrome and sciatica. Eur Spine J. 1994; 3(5): 265-9.

\author{
Correspondence to / Autor za korespondenciju \\ Emilija Stojkovska-Pemovska MD, traumatologist \\ University Clinic of Traumatology, \\ Medical faculty of Skopje \\ MajkaTereza 17, 1000 Skopje, Macedonia. \\ e-mail: emilija60@yahoo.com \\ phone: +38971351050
}

